\title{
AKAR KOMUNIKASI DALAM AL-QUR'AN
}

\author{
(Studi Tematik Dimensi Komunikasi Dalam Al-Qur'an)
}

\author{
Ali Nurdin \\ Program Studi Ilmu Komunikasi, \\ Fakultas Dakwah dan Komunikasi UIN Sunan Ampel Surabaya
}

\begin{abstract}
ABSTRAK
Tema penelitian ini adalah “Akar Komunikasi dalam Al-Qur'an” yang sengaja dipilih dengan tujuan menjelaskan akar komunikasi: intrapersonal, interpersonal, komunikasi massa, antar budaya, dan komunikasi organisasi dalam al - Qur'an dan menjelaskan relevansi konsep komunikasi dalam Al-Qur'an dengan konsep komunikasi dalam perspektif ahli komunikasi. Penelitian ini menggunakan metode deskriptif kualitatif berdasarkan kajian literatur dengan pendekatan penafsiran tematik. Sumber data utama dan pertama dalam penelitian ini adalah Al-Qur'an. Sumber-sumber lain adalah berbagai tafsir buku terbatas pada buku-buku tafsir yang dianggap representatif dan tersedia, yaitu: tafsir Al-Qur'an Al-Mishbah dan tafsir Al-Qur'an Al-Adzim. Studi ini menemukan bahwa akar dari komunikasi intrapersonal di AlQur'an menempatkan pikiran (immaterial) sebagai pusat kontrol untuk jiwa untuk memberikan rangsangan kepada indera pendengaran dan penglihatan (material), dan menghasilkan pikiran. Akar komunikasi interpersonal di Al-Qur'an lebih didasarkan pada etika komunikasi atau bagaimana berbicara dengan orang lain dengan kebijaksanaan, mauidhah, dan Mujadalah. Ini didasarkan pada prinsip sadidan qawlan, balighan qawlan, qawlan maysuran, layyinan qawlan, qawlan Kariman, qawlan ma'rufan. Akar komunikasi massa di Al-Qur'an menempatkan dirinya sebagai pusat informasi / berita yang memiliki kebenaran mutlak. Al-Qur'an memberikan pedoman bagi manusia dalam memberikan informasi / berita kepada orang lain yang harus disertai dengan kejujuran, keadilan, akurasi, dan dapat dipertanggungjawabkan. Al-Qur'an mendesak masyarakat untuk berhati-hati (tidak mudah percaya) dalam menerima informasi atau berita. Akar komunikasi antar budaya dalam Al-Qur'an dimulai dari sifat manusia diciptakan di dunia untuk mengenal satu sama lain (komunikasi) dengan keragaman latar belakang agama, etnis, bangsa, jenis kelamin dan sebagainya. Akar dari komunikasi organisasi di Al-Qur'an memerintahkan beberapa orang untuk membentuk suatu organisasi atau lembaga untuk mengoptimalkan upaya amar ma'ruf dan nahi munkar (memerintahkan kebaikan dan mencegah keburukan). Konsep keterkaitan komunikasi dalam Al-Qur'an dengan konsep komunikasi Barat mengandung nilai menjelaskan satu sama lain. Ini berarti bahwa bagi umat Islam, Al-Qur'an adalah pedoman hidup, sedangkan komunikasi barat dapat digunakan untuk menjelaskan makna dari isi Al-Qur'an.
\end{abstract}

Kata Kunci : Akar komunikasi, intrapersonal, interpersonal, komunikasi massa, antarbudaya, komunikasi organisasi, Al-Qur'an

\section{ROOT OF COMMUNICATION IN AL-QURAN}

\begin{abstract}
Research entitled "roots of communication in Al-Qur'an" is deliberately chosen with the aim of explaining the roots of communication of intrapersonal, interpersonal, mass communication, intercultural, and organizational communication / groups within AlQur'an, and explaining the relevance of communication concepts in the Qur'an with the concept of communication in perspective of communication expert. This study uses a qualitative descriptive method, based on a literature review with thematic interpretation approach. The main and first data sources in this study is Al-Qur'an. Other sources are variety of tafsir books limited to the tafsir books that are considered representative and available, namely: tafsir Al-Qur'an Al-Mishbah and tafsir Al-Qur'an Al-Adzim. The study found that the roots of intrapersonal communication in Al-Qur'an puts the mind (immaterial) as the control center for the soul to give stimuli to the senses of hearing and sight (material), and produces a thought. The root of interpersonal communication in AlQur'an is more grounded in the ethics of communication or how to talk to others with wisdom, mauidhah, and mujadalah. These are based on the principle of qawlan sadidan, qawlan balighan, qawlan maysuran, qawlan layyinan, qawlan kariman, qawlan ma'rufan. The root of mass communication in Al-Qur'an puts Al-Qur'an itself as a center of information / news that has the absolute truth. The Qur'an provides guidance for man in giving information / news to others that must be accompanied by honesty, fairness, accuracy, and can be accounted for. Al-Qur'an urges the public to be careful (not easy to believe) in receiving information or news. The roots of intercultural communication in Al-Qur'an is started from the nature of man created in the world to know each other (communication) with the diversity of religious background, ethnicity, nation, gender and so on. The root of the organization communication in Al-Qur'an orders some people to form an organization or institution to optimize the effort of amar ma'ruf and nahi munkar (commanding the good and forbidding the evil). The linkage concept of communication in Al-Qur'an with the concept of the West communication contains the value of explaining each other. This means that for Muslims Al-Qur'an is life guidance, while the west communication can be used to explain the meaning of the content in Al-Qur'an.
\end{abstract}

Keywords: Root of Communications, intrapersonal, interpersonal, mass communication, intercultural, organizational communication, Al-Qur'an

Korespondensi: Dr. Ali Nurdin, S.Ag, M.Si. Program Studi Ilmu Komunikasi, Fakultas Dakwah dan Komunikasi UIN Sunan Ampel Surabaya. Jl. Jend. A. Yani. 117 Surabaya. Email: ali.nurdin@uinsby.ac.id 


\section{PENDAHULUAN}

Allah SWT telah memberi banyak fasilitas untuk dapat berkomunikasi bagi diri manusia maupun pada lingkungan hidupnya. Segala apa yang ada di sekitar manusia dapat dimanfaatkan untuk berkomunikasi dengan lingkungan sekelilingnya, semuanya dapat digunakan sebagai pesan, simbol, saluran, media, isyarat, kode (sandi), informasi, berita, dan bahasa (Muis, 2001: 41).

Manusia mempunyai sifat dasar yaitu rasa ingin tahu, bahkan ingin mengetahui apa yang terjadi dalam dirinya. Manusia juga mempunyai rasa ingin berhubungan dengan manusia lainnya. Rasa keinginan manusia tersebut memaksa manusia untuk berkomunikasi sebagai makhluk sosial.

Komunikasi jelas tidak dapat dipisahkan dengan kehidupan umat manusia, baik sebagai individu maupun sebagai anggota masyarakat. Komunikasi dibutuhkan untuk mengatur tatakrama pergaulan antar manusia. Dengan demikian komunikasi merupakan salah satu aktivitas yang sangat fundamental dalam kehidupan umat manusia, sebab dengan komunikasi yang baik akan memberi pengaruhlangsung padastrukturkeseimbangan seseorang dalam bermasyarakat, apakah ia seorang dokter, dosen, manajer, pedagang, petani, pemuka agama dan lain sebagainya, faktor komunikasi juga dapat menentukan keberhasilan dan kegagalan seseorang dalam mencapai sesuatu yang diinginkan.

Fenomena inilah yang menarik untuk dikaji dan dijadikan sebagai pedoman dalam komunikasi yang berlandaskan dan berprinsip pada komunikasi Islami. Sesungguhnya Allah SWT sejak menurunkan wahyu pertamanya dalam surat Al-'Alaq adalah perintah untuk membaca. Hal ini mengindikasikan bahwa pada setiap manusia diberikan anugrah berupa kemampuan untuk membaca dirinya dan juga lingkungan sekelilingnya. Proses membaca ini merupakan salah satu implementasi dari komunikasi intrapersonal yang berproses pada diri manusia.

Al-Qur'an telah banyak memberikan petunjuk berkaitan dengan masalah-masalah sosial kemasyarakatan. Bahkan jumlah ayatayat tersebut lebih banyak dibandingkan dengan ayat-ayat ibadah mahdhah. Jumlahn- ya berbanding 228 : 140 (Nasution, 1986: 30). Memang dalam Islam tidak mengenal kata atau defenisi komunikasi dan ilmu komunikasi. Baik di dalam Al-Qur'an maupun Hadits tidak akan ditemui kata dan pengertian tersebut. Namun demikian, dari kedua sumber ajaran Islam tersebut, dapat ditemukan beberapa prinsip dasar yang berkaitan dengan komunikasi (Amir, 1999,11).

Metode komunikasi interpersonal juga banyak dijumpai dalam al-Qur'an. Dalam ilmu komunikasi, komunikasi interpersonal ini dapat dimaknai sebagai situasi yang memungkinkan terjadinya dialog antara komunikator dan komunikan (Effendy, 2000: 27). Al-Qur'an sering menggunakan metode dialog ini dari cara Allah memanggil manusia, orang-orang beriman, ahli kitab, Bani Israil dan lain sebagainya serta dari redaksi para nabi dan rasul memanggil kaum, anak, bapak mereka dan lain sebagainya. Istilah-istilah yang dipergunakan adalah $Y a$ dan $Y a$ Ayyuha yang artinya wahai, hai. Metode dialog di dalam Al-Qur'an sebagian juga dapat diketahui dari kisah para nabi dan rasul. Mereka berdialog dengan kaum, penguasa, sesama nabi dan rasul, bahkan di antara mereka berdialog langsung dengan Allah. Salah satu ayat yang menunjukkan hal tersebut adalah dialog antara Nabi Ibrahim dengan anaknya (Isma'il) dalam surat Ash Shaffaat ayat 102 sebagai berikut;

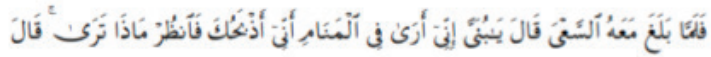

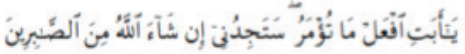

Artinya; "Maka tatkala anak itu sampai (pada umur sanggup) berusaha bersama-sama Ibrahim, Ibrahim berkata: "Hai anakku sesungguhnya aku melihat dalam mimpi bahwa aku menyembelihmu. Maka fikirkanlah apa pendapatmu!" ia menjawab: "Hai bapakku, kerjakanlah apa yang diperintahkan kepadamu; insya Allah kamu akan mendapatiku termasuk orang-orang yang sabar"(QS. Ash Shaffaat: 102).

Bidang-bidang komunikasi yang lain juga mengindikasikan adanya indikator proses penyampaian pesan termaktub dalam Al- 
Qur'an. Indikator tersebut salah satunya tampak pada ayat ke-13 dari surat Al-Hujurat sebagai berikut:

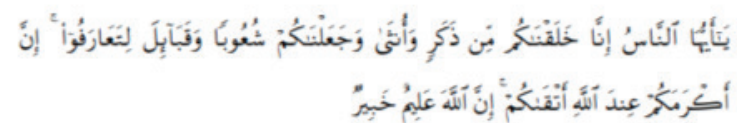

Artinya; "Hai manusia, Sesungguhnya kami menciptakan kamu dari seorang laki-laki dan seorang perempuan dan menjadikan kamu berbangsa-bangsa dan bersuku-suku supaya kamu saling kenAl-mengenal. Sesungguhnya orang yang paling mulia diantara kamu disisi Allah ialah orang yang paling taqwa diantara kamu. Sesungguhnya Allah Maha mengetahui lagi Maha Mengenal"'(QS. Al-Hujurat: 13).

Fenomena komunikasi dalam Al-Qur'an sesungguhnya telah lama ada sejak wahyu tersebut diiturunkan pertama kali. Namun karena perkembangan dan istilah ilmu komunikasi tersebut lahir dan berkembang di negara-negara barat, maka sentuhan komunikasi ilahiyahnya menjadi berkurang dan bahkan tidak ada sama sekali. Oleh karena itu pada penelitian ini akan mencoba menjelaskan klasifikasi ayat-ayat AlQur'an berdasarkan tema-tema komunikasi perspektif ilmu komunikasi yang telah berkembang. Penelitian ini juga akan menjelaskan peristiwa-peristiwa komunikasi dan klasifikasinya yang terjadi dalam al-Qur'an dan konteks yang melingkupinya. Dengan demikian penelitian ini sangatlah penting dilakukan sebagai upaya membangun kerangka berpikir dan paradigma baru tentang komunikasi yang bersumber dan berlandaskan pada Al-Qur'an.

Rumusan masalah dalam penelitian ini adalah bagaimana akar komunikasi intrapersonal, komunikasi interpersonal, komunikasi massa, komunikasi antarbudaya, dan komunikasi organisasi dalam Al-Qur'an, serta bagaimana keterkaitan konsep komunikasi dalam AlQur'an dengan konsep komunikasi dalam perpektif pakar ilmu komunikasi. Untuk itu, penelitian ini bertujuan untuk menjelaskan akar komunikasi intrapersonal, komunikasi interpersonal, komunikasi massa, komunikasi antarbudaya, dan komunikasi organisasi/ kelompok yang ada dalam al-Qur'an dan menjelaskan ket- erkaitan konsep komunikasi dalam Al-Qur'an dengan konsep komunikasi dalam perpektif pakar ilmu komunikasi.

\section{METODE PENELITIAN}

Penelitian ini menggunakan metode deskriptif kualitatif dengan berbasis pada kajian pustaka dengan pendekatan tafsir tematik. Sumber data utama dan pertama dalam penelitian ini adalah Kitab Suci Al-Qur'an. Sumber-sumber lainnya adalah kitab-kitab Tafsir yang dibatasi pada kitab-kitab yang dipandang representatif dan tersedia, yaitu: Tafsir Al-Qur'an Al-Mishbah (Pesan, Kesan, dan Keserasian AlQur'an) karangan M. Quraish Shihab dan Tafsir Al-Qur'an Al-Adzim karangan Isma'il Ibnu Al-Katsir al Quraishi Al-Dimashqi yang lebih dikenal dengan Ibnu Katsir, dan lain-lain yang relevan.

\section{HASIL DAN PEMBAHASAN}

Pertama, akar komunikasi intrapersonal dalam Al-Qur'an. Untuk memberi arah yang jelas keterkaitan konsep komunikasi dalam alQur'an diperlukan definisi komunikasi intrapersonal yang akan digunakan sebagai pijakan untuk mengklasifikasi ayat terkait dengan komunikasi.

Komunikasi intrapersonal adalah komunikasi transaksi yang mengambil tempat di dalam individu atau di sebut juga dengan communication with self. Komunikasi intrapersonal adalah komunikasi yang berlangsung dalam diri seseorang. Orang itu berperan baik sebagai komunikator maupun sebagai komunikan. Dia berbicara kepada dirinya sendiri, dia berdialog dengan dirinya sendiri. Dia bertanya kepada dirinya dan dijawab oleh dirinya sendiri (Effendy, 2000: 58).

Proses komunikasi intrapersonal terjadi melalui proses-proses seperti sensasi, asosiasi, persepsi, memori, dan berpikir. Sensasi adalah proses pencerapan informasi (energi/stimulus) yang datang dari luar melalui panca indra. Asosiasi adalah pengalaman dan kepribadian yang mempengaruhi proses sensasi. Persepsi ada- 
lah pemaknaan/ arti terhadap informasi (energi/ stimulus) yang masuk ke dalam kognisi manusia. Memori adalah stimuli yang telah diberi makna di rekam dan disimpan dalam otak (memori) manusia. Berpikir adalah akumulasi dari proses sensasi, asosiasi, persepsi, dan memori yang dikeluarkan untuk mengambil keputusan (Syam: 2010).

Penjelasan Al-Qur'an tentang komunikasi intrapersonal dimulai dari awal ketika Nabi Adam as. diciptakan dan diberi pengetahuan oleh Allah tentang nama-nama benda yang ada di sekitarnya melalui ayat-ayat berikut:

1) Surat $\mathrm{Al}$ - Baqarah ayat 31

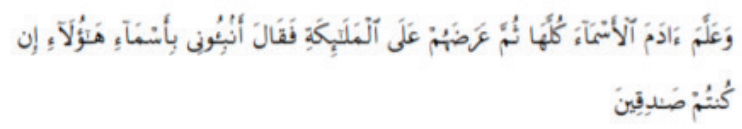

Artinya; Dan dia mengajarkan kepada Adam nama-nama (benda-benda) seluruhnya, Kemudian mengemukakannya kepada para malaikat lalu berfirman: "Sebutkanlah kepada-Ku nama benda-benda itu jika kamu mamang benar orang-orang yang benar (QS. Al Baqoroh: 31).

Kata kunci dalam ayat ini adalah 'allama, yaitu mengajar. Mahmud Yunus dalam kamus Bahasa Arab mengartikan $\mathcal{E} \mathcal{C}^{2}$ dengan makna melatih, memberi tanda (Yunus, 1973: 27). Dalam tafsir Al Misbah diterangkan bahwa Allah telah mengajar ( 'allama) Adam nama-nama seluruhnya, yaitu memberinya potensi pengetahuan tentang nama-nama atau kata-kata yang digunakan untuk menunjuk benda-benda, atau mengajari fungsi benda-benda (Shihab, 2002: 143). Dalam konteks lain, 'allama dapat di maknai sebagai 'mengetahui' yang biasanya ditentukan oleh akal atau setidaknya dibutuhkan akal untuk mencapainya. Allah mengajari Adam mengenal dan menyebut nama-nama benda tersebut dengan cara memberikan kemampuan akal atau rasio (Shihab, 2002: 143).

Ayat ini menginformasikan bahwa manusia dianugrahi Allah potensi untuk mengetahui nama-nama atau fungsi-fungsi dan karakteristik benda-benda, misalnya fungsi api, fungsi angin, dan sebagainya. Dia juga dianugrahi potensi untuk berbahasa. Sistem pengajaran bahasa kepada manusia (anak kecil) bukan dimulai dari kata kerja, tetapi mengajarnya lebih dahulu nama-nama. Ini ayah, ini ibu, itu mata, itu telinga, dan sebagainya.

Sebagian ulama memahami 'allama sebagai mengajarkan kata-kata, dengan menyebut nama-nama benda tertentu dengan mendengar suara yang menyebut nama benda tersebut. Namun ada juga yang berpendapat bahwa Allah 'mengilhamkan' kepada Adan as nama benda itu pada saat dipaparkannya sehingga beliau memiliki kemampuan untuk memberi kepada masing-masing benda nama-nama yang membedakannya dari benda-benda yang lain.

Salah satu keistemewaan manusia adalah kemampuannya mengekspresikan apa yang terlintas dalam benaknya serta kemampuannya menangkap bahasa sehingga dapat mengantarkannya untuk mengetahui. Di sisi lain kemampuan manusia untuk merumuskan ide dan memberi nama bagi segala sesuatu merupakan langkah menuju terciptanya manusia berpengetahuan dan lahirnya ilmu pengetahuan (Shihab. 2002, 144).

Surat an Nuur ayat 23-24

Di sisi lain, pemahaman tentang pesan-pesan melalui indera manusia dijelaskan dalam Al-Qur'an sebagai berikut:

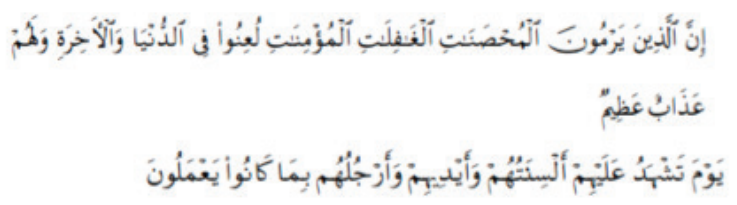

Artinya; "Sesungguhnya orang-orang yang menuduh wanita yang baik-baik, yang lengah lagi beriman (berbuat zina), mereka kena la'nat di dunia dan akhirat, dan bagi mereka azab yang besar. Pada hari (ketika), lidah, tangan dan kaki mereka menjadi saksi atas mereka terhadap apa yang dahulu mereka kerjakan" (QS. An Nuur: 23-24)

Penegasan pada ayat 24 sebenarnya terkait dengan seseorang (wanita) yang dituduh berbuat zina tanpa ada saksi, dan Allah menegaskan kekuasaanNya dengan memberi kemampuan lidah, tangan dan kaki untuk dapat bersaksi atas perbuatan masa lalu mereka. Pembicaraan lidah, tangan, dan kaki banyak ditegaskan oleh AlQur'an. Namun ulama berbeda pendapat tentang hakikatnya. Ada yang berpendapat bahwa 
yang dimaksud adalah tampaknya bekas-bekas perbuatan dan dosa mereka pada anggota tubuh itu, dan ada juga yang memahaminya dalam arti hakiki, yakni memang anggota tubuh berbicara, sebagaimana lidah kita sekarang berbicara. Penyebutan anggota tubuh tertentu pada ayat di atas agaknya disebabkan karena organ-organ itulah yang berperan besar dalam penyebaran isu itu, yakni lidah dan mulut yang bercakap, tangan yang menunjuk dan kaki yang berjalan ke kiri dan ke kanan menyebarkan isu itu ke mana-mana (Shihab, 2002: 313).

2) Surat Yasin ayat 65

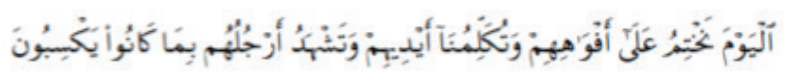

Artinya; "Pada hari ini kami tutup mulut mereka; dan berkatalah kepada kami tangan mereka dan memberi kesaksianlah kaki mereka terhadap apa yang dahulu mereka usahakan" (QS. Yasin: 65)

Pada surat Yasin ayat 65 juga ditegaskan lagi tentang kesaksian atau pembicaraan yang dilakukan oleh indera tangan dan kaki manusia sebagai saksi atas segala yang diperbuat selama hidup di dunia. Pada hari itu Kami yakni Allah SWT menutup mulut mereka sehingga mulut itu terdiam tidak dapat berbohong bahkan tidak dapat berbicara; dan bercakap kepada Kami tangan mereka mengakui dan menyaksikan kedurhakaan yang pernah diperbuat pelakunya melalui tangan itu dan bercakap juga serta memberi kesaksian kaki mereka atas dosa-dosa yang pernah dikerjakannya. Demikian juga semua bagian dari totalitas diri manusia, seperti mata, telinga dan hati (semua tampil) mengaku dan bersaksi menyangkut apa yang dahulu mereka selalu lakukan (Shihab, 2002: 564).

Pada ayat lain juga menerangkan bahwa pendengaran dan penglihatan, serta kulit-pun akan dimintai pertanggungjawabannya. Dalam surat Fushshilat ayat 20 menyebutkan:

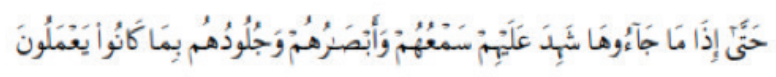

Artinya; "Sehingga apabila mereka sampai ke neraka, pendengaran, penglihatan dan kulit mereka menjadi saksi terhadap mereka tentang apa yang telah mereka kerjakan"(QS. Fushshilat: 20)

\section{3) Surat Al-Isra' ayat 36}

Dalam surat Al-Isra' ayat 36 juga disebut antara lain hati yang akan dimintai pertanggungjawabannya. Jika demikian, maka yang disebut oleh ayat surat ini, hanyalah contoh dari tampilnya seluruh bagian dari diri manusia untuk mengakui kesalahan dan dosanya. Ayat tersebut berbunyi;

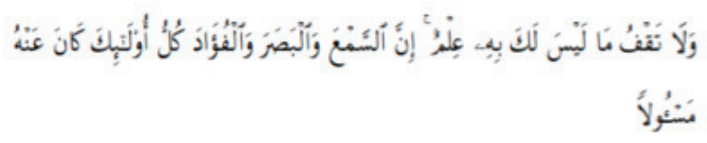

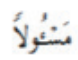

Artinya; "Dan janganlah kamu mengikuti apa yang kamu tidak mempunyai pengetahuan tentangnya. Sesungguhnya pendengaran, penglihatan dan hati, semuanya itu akan diminta pertanggungan jawabnya" (QS. Al-Isra': 36).

Ayat ini memerintahkan; lakukan apa yang telah Allah perintahkan dan hindari apa yang tidak sejalan dengannya, dan janganlah engkau mengikuti apa-apa yang tiada bagimu pengetahuan tentangnya. Jangan berucap apa yang engkau tidak ketahui, jangan mengaku tahu apa yang engkau tidak tahu atau mengaku mendengar apa yang engkau tidak dengar. Sesungguhnya pendengaran, penglihatan, dan hati merupakan alat pengetahuan yang nantinya dimintai pertanggungjawaban dari apa yang dilakukan oleh pemiliknya (Shihab, 2002: 464).

Dijadikannya pendengaran, penglihatan, dan hati adalah sebagai bekal dan alat-alat untuk meraih pengetahuan sesuai dengan tujuan Allah menganugerahkannya kepada manusia. Ayat ini menggunakan kata ( عمسل assam/ pendengaran dengan bentuk tunggal dan menempatkannya sebelum kata (راصبأل) Al-abshar/ penglihatan-penglihatan yang berbentuk jamak serta ( مدى (Al-af'idah/ aneka hati yang berbentuk jamak. Kata $A l$ af'idah adalah bentuk jamak dari kata ( داوف ) fu'ad yang diterjemahkan sebagai 'aneka hati' guna menunjuk makna jamak tersebut. Kata ini banyak dipahami oleh para ulama dalam arti 'akal'. Makna ini dapat diterima jika yang di- 


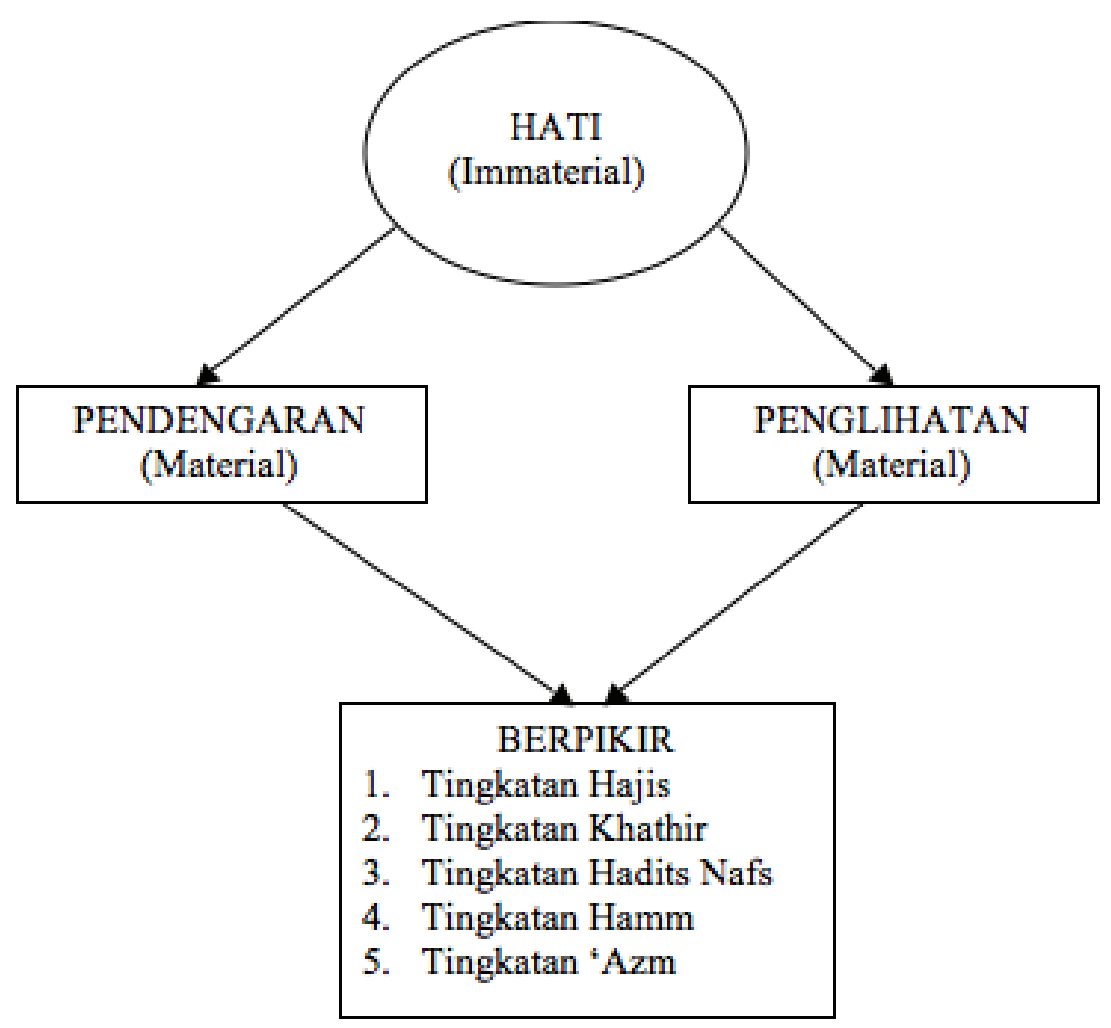

Gambar 2. 1 Proses Komunikasi Intrapersonal dalam al-Qur'an

maksud dengannya adalah gabungan daya pikir dan daya kalbu, yang menjadikan seseorang terikat sehingga tidak terjerumus dalam kesalahan dan kedurhakaan (Shihab, 2002: 303). Dengan demikian maka didalamnya mengandung pengertian potensi meraih ilham dan percikan cahaya ilahi.

Ayat di atas menjelaskan tentang alat-alat pokok yang digunakan untuk meraih pengetahuan. Alat pokok yang ada pada obyek yang bersifat material adalah mata dan telinga, sedangkan obyek yang bersifat immaterial adalah akal dan hati.

Dalam pandangan Al-Qur'an ada wujud yang tidak tampak meskipun mata kepala atau pikiran sangat tajam. Banyak hal yang tidak terjangkau oleh indera bahkan akal manusia. Yang dapat menangkapnya adalah hanya dengan hati, melalui wahyu, ilham atau intuisi. Dari sinilah kemudian Al-Qur'an selalu menuntun dan mengarahkan pendengaran dan penglihatan, dan juga memerintahkan agar mengasah akal yakni daya pikir melalui hati.

Penjelasan ayat-ayat yang telah diuraikan di atas membawa pemahaman bahwa ada indikasi-indikasi yang sama antara proses komunikasi intrapersonal dengan yang telah tertuang dalam Al-Qur'an. Jika digambarkan model komunikasi intrapersonal dalam Al-Qur'an adalah seperti pada Gambar 1 di atas.

\section{Keterangan:}

1. Hati, kata ini banyak dipahami oleh para ulama dalam arti 'akal' yaitu gabungan daya pikir dan daya kalbu, yang menjadikan seseorang terikat sehingga tidak terjerumus dalam kesalahan dan kedurhakaan. Akal dan mata hati berfungsi membedakan yang baik dan buruk berfungsi jauh sesudah pendengaran dan penglihatan yang ada pada seorang manusia. Dalam pandangan Al-Qur'an ada wujud yang tidak tampak meskipun mata kepala atau pikiran sangat tajam. Banyak hal yang tidak terjangkau oleh indera bahkan akal manusia. Yang dapat menangkapnya adalah hanya dengan hati, melalui wahyu, ilham atau intuisi. Dengan demikian, maka komunikasi intrapersonal dalam Al-Qur'an menempatkan hati (immaterial) sebagai pusat pengendali komunikasi dalam diri manusia.

2. Pendengaran dan penglihatan sebagai tempat 
proses penangkapan dari stimuli yang diinginkan oleh hati dan kemudian diberi makna.

3. Berpikir adalah akumulasi dari keinginan hati yang dipancarkan ke pendengaran dan penglihatan. Manusia berpikir melalui beberapa tingkatan yaitu Hajis yaitu sesuatu yang terlintas dalam pikiran seseorang secara spontan dan berakhir seketika (tingkatan terendah). Khathir yaitu yang terlintas sejenak kemudian berhenti. Hadits nafs yaitu bisikan-bisikan hati yang dari saat ke saat muncul dan bergejolak. Hamm yaitu kehendak melakukan sesuatu sambil memikirkan cara-cara pencapaiannya. 'Azm yaitu kebulatan tekad setelah rampungnya seluruh proses hamm dan dimulainya langkah awal bagi pelaksanaan aktivitas komunikasi (tingkatan tertinggi).

Kedua, akar komunikasi interpersonal dalam Al-Qur'an. Penjelasan Al-Qur'an tentang komunikasi interpersonal dimulai ketika Nabi Ibrahim as. dialog dengan putranya Nabi Ismail as. dalam ayat sebagai berikut:

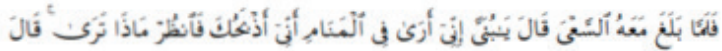

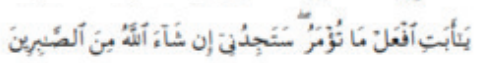

Artinya; "Maka tatkala anak itu sampai (pada umur sanggup) berusaha bersama-sama Ibrahim, Ibrahim berkata: "Hai anakku sesungguhnya aku melihat dalam mimpi bahwa aku menyembelihmu. Maka fikirkanlah apa pendapatmu!" ia menjawab: "Hai bapakku, kerjakanlah apa yang diperintahkan kepadamu; insya Allah kamu akan mendapatiku termasuk orang-orang yang sabar"(QS. Ash Shaffaat: 102).

Deskripsi atau cermin komunikasi interpersonal terlihat dalam dialog antara Nabi Ibrahim as. dengan putranya Nabi Ismail yang didalamnya terkandung nilai komunikasi yang memiliki nilai etika tinggi dalam penggunaan bahasa. Berikut pendapat M. Quraish Shihab tentang ayat ini; ayat ini menggunakan kata kerja mudhari' (masa kini dan akan datang) pada kata-kata adzbahuka (saya menyembelihmu). Demikian juga kata رؤث tu'mar (diperintahkan). Hal ini untuk mengisyaratkan bahwa apa yang be- liau lihat itu seakan-akan masih terlihat hingga saat penyampaiannya. Sedang penggunaan bentuk tersebut untuk kata menyembelihmu untuk mengisyaratkan bahwa perintah Allah yang dikandung mimpi itu belum selesai dilaksanakan, tetapi hendaknya segera dilaksanakan. Karena itu pula jawaban sang anak menggunakan kata kerja masa kini juga untuk mengisyaratkan bahwa ia siap, dan bahwa hendaknya sang ayah melaksanakan perintah Allah yang sedang maupun yang akan diterimanya (Shihab, 2002: 63).

\section{2) Surat al-A'raf ayat 143}

Akar komunikasi interpersonal dalam AlQur'an tercermin dalam permintaan dialog yang dilakukan oleh nabi Musa as kepada Allah SWT sebagaimana tertera dalam surat al-A'raf ayat 143 sebagai berikut:

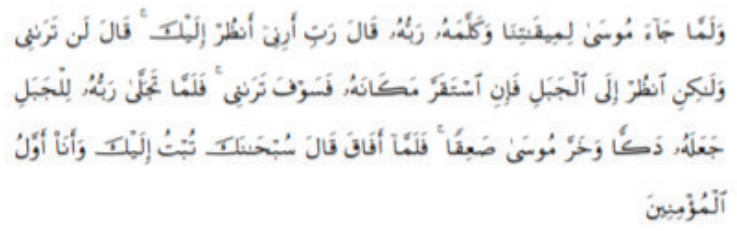

Artinya; "Dan tatkala Musa datang untuk (munajat dengan kami) pada waktu yang telah kami tentukan dan Tuhan telah berfirman (langsung) kepadanya, berkatalah Musa: "Ya Tuhanku, nampakkanlah (diri Engkau) kepadaku agar Aku dapat melihat kepada Engkau”. Tuhan berfirman: "Kamu sekali-kali tidak sanggup melihat-Ku, tapi Lihatlah ke bukit itu, Maka jika ia tetap di tempatnya (sebagai sediakala) niscaya kamu dapatmelihat-Ku”. tatkala Tuhannya menampakkan diri kepada gunung itu, dijadikannya gunung itu hancur luluh dan Musa pun jatuh pingsan. Maka setelah Musa sadar kembali, dia berkata: "Maha Suci Engkau, Aku bertaubat kepada Engkau dan Aku orang yang pertama-tama beriman"'(QS. al-A'raf: 143)

Pembahasan ini tidak bermaksud untuk mencari akar masalah teologi tentang subtansi bahwa benarkah Allah itu dapat dilihat atau tidak. Namun kontek yang perlu digaris bawahi dalam ayat ini adalah permintaan dialog nabi Musa as. yang mencerminkan adanya konsep komunikasi interpersonal dalam Al-Qur'an. 
Dalam surat Asy-Syura ayat 51 juga diterangkan tentang penerimaan wahyu yang berkaitan dengan kegiatan berbicara antara Allah dengan para rasul-Nya yaitu:

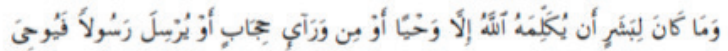

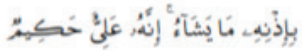

Artinya : "Dan tidak mungkin bagi seorang manusiapun bahwa Allah berkata-kata dengan dia kecuali dengan perantaraan wahyu atau dibelakang tabir atau dengan mengutus seorang utusan (malaikat) lalu diwahyukan kepadanya dengan seizin-Nya apa yang dia kehendaki. Sesungguhnya dia Maha Tinggi lagi Maha Bijaksana" (QS. Asy-Syura: 51).

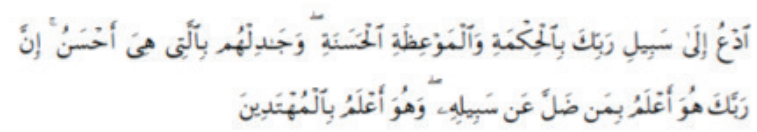

Artinya; "Serulah (manusia) kepada jalan Tuhan-mu dengan hikmah dan pelajaran yang baik dan bantahlah mereka dengan cara yang baik. Sesungguhnya Tuhanmu dialah yang lebih mengetahui tentang siapa yang tersesat dari jalan-Nya dan dialah yang lebih mengetahui orang-orang yang mendapat petunjuk" (QS. An-Nahl: 125).

Kata kunci dalam ayat ini adalah ة̈, dan مأظع ومل داج. M. Quraish Shihab (Shihab, 2002: 386-387) mengartikan sebagai yang paling utama dari segala sesuatu, baik pengetahuan maupun perbuatan. Hikmah adalah pengetahuan dan tindakan yang bebas dari kesalahan atau kekeliruan. Hikmah juga diartikan sebagai sesuatu yang bila dipergunakan/ diperhatikan akan mendatangkan kemaslahatan dan kemudahan yang besar atau lebih besar, serta menghalangi terjadinya mudharat atau kesulitan yang besar atau lebih besar.

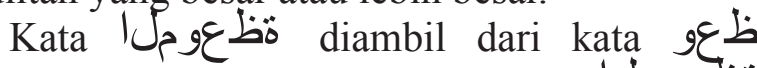

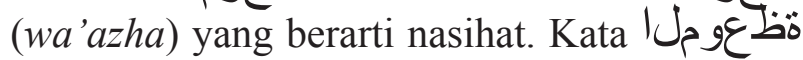
diartikan sebagai uraian yang menyentuh hati yang mengantar kepada kebaikan. Sedangkan kata jo diambil dari kata Jادج (jidal) yang bermakna diskusi atau bukti-bukti yang mematahkan alasan atau dalih mitra diskusi dan menjadikannya tidak dapat bertahan, baik yang dipaparkan itu diterima oleh semua orang mau- pun hanya oleh mitra bicara.

Dalam ayat ini juga dijelaskan bahwa kata ةظ hendaknya disampaikan dengan )

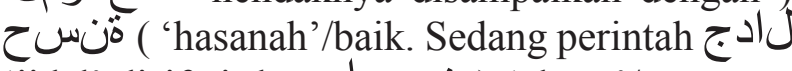
'jidal' disifati denga|نسح ( نس ) 'ahsan'/yang terbaik, bukan sekedar yang terbaik. Keduanya berbeda dengan ثَح ' 'hikmah' yang tidak disifati oleh sifat apapun. Ini berarti bahwa ةظ 'mau'izhah' ada yang baik dan ada yang tidak baik, sedang لزادج ‘jidal' ada tiga macam, yang baik, yang terbaik, dan yang buruk. Hikmah tidak perlu disifat dengan sesuatu karena dari maknanya telah diketahui bahwa ia adalah sesuatu yang mengena kebenaran berdasar ilmu dan akal.

Ayat di atas merupakan contoh konkrit bagaimana Allah telah membentuk kepribadian Nabi Muhammad SAW. Kepribadian beliau dibentuk sehingga bukan hanya pengetahuan yang Allah limpahkan kepada beliau melalui wahyu-wahyu Al-Qur'an, tetapi juga kalbu beliau disinari, bahkan totalitas wujud beliau merupakan rahmat bagi seluruh alam.

Ayat-ayat di atas telah memberikan pengertian bahwa contoh komunikasi interpersonal telah diperagakan melalui dialog Nabi Ibrahim dengan putranya Nabi Ismail, demikian juga tentang permintaan Nabi Musa untuk berdialog langsung kepada Allah. Komunikasi interpersonal yang ada dalam Al-Qur'an lebih banyak mengatur etika komunikasi ketika berhadapan dengan orang orang lain. Penggunaan bahasa yang penuh hikmah, bijaksana, dan ketika berbantahan atau diskusi juga dengan menggunakan argumen yang santun dalam mengalahkan pihak lawan. Komunikasi dengan menggunakan bahasa yang sopan, dan lemah lembut menjadi kekuatan dalam berkomunikasi dengan orang lain. Bahkan prinsip-prinsip komunikasi dalam Al-Qur'an semuanya berawal dari etika komunikasi yaitu; qawlan sadidan yaitu pembicaraan yang benar, jujur, lurus, tidak bohong, tidak berbelit-belit (QS. An Nissa': 9, Al Ahzab: 70), qawlan balighan yaitu komunikasi yang jelas maknanya, terang, dan tepat mengungkapan apa yang dikehendaki (komunikasi efektif) (QS. An Nissa': 63), qawlan maysuran yaitu perkataan yang pantas, yang tidak menimbulkan ketersinggungan pada orang lain (QS. Al Isra': 28), qawlan layyinan yaitu kata-kata yang lemah lembut (QS. Thaahaa: 44), qawlan kariman yaitu perkataan yang mulia, 
yang tidak membuat orang marah (QS. Al Isra': 23), dan qawlan ma'rufan yaitu kata-kata yang baik (QS. An Nissa': 5).

Ketiga, akar komunikasi massa dalam Al Qur'an. Komunikasi massa yang dimaksud pada penelitian ini bukanlah konsep komunikasi massa dalam pengertian secara umum. Artinya komunikasi yang menggunakan media seperti media cetak (surat kabar, majalah, tabloid dan sebagainya) dan media elektronik (radio, televisi, dan internet), namun komunikasi massa dalam Al-Qur'an ini bermakna konsep yang substansinya lebih pada materi media, yaitu berita. Substansi berita dalam media inilah yang akan digali konsepnya dalam kandungan ayat-ayat Al-Qur'an.

Media sangat terkait erat dengan berita, oleh karena itu bagaimana cara memberitakannya inilah yang akan dicoba digali dalam Al-Qur'an.

1) Surat Al-Alaq ayat 1

Tema yang pertama adalah perintah Allah untuk membaca yang termaktub dalam surat Al-Alaq ayat 1 sebagai berikut;

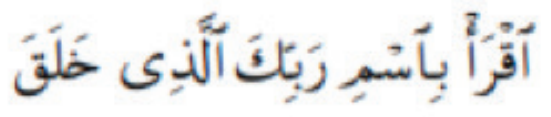

Artinya; "Bacalah dengan (menyebut) nama Tuhanmu yang Menciptakan” (QS. Al-Alaq: 1).

Secara umum ayat ini menjelaskan tentang pentingnya membaca, membaca apa saja yang ada disekeliling lingkungan kita termasuk media. Menurut M. Quraish Shihab (Shihab, 2002: 392-393), kata أرق iqra' diambil dari kata kerja ارق qara'a yang pada mulanya berarti menghimpun. Di dalam kamus, arti kata ini banyak diartikan antara lain menyampaikan, menelaah, membaca, mendalami, meneliti, mengetahui ciri-ciri sesuatu dan sebagainya yang kesemuanya itu bermuara pada arti menghimpun. Ayat ini juga tidak menyebut obyek bacaan secara detail, oleh karena itu ada kaidah kebahasaan yang mengatakan bahwa: apabila suatu kata kerja yang membutuhkan obyek tetapi tidak disebutkan obyeknya, maka obyek yang di maksud bersifat umum, menyangkut segala sesuatu yang dapat dijangkau oleh kata tersebut. Dengan demikian maka dapat disimpulkan bahwa karena kata iqra' digunakan da- lam arti membaca, menelaah, menyampaikan, dan sebagainya, dan karena obyek nya bersifat umum, maka obyek kata tersebut mencakup segala yang dapat terjangkau, maka perintah iqra' mencakup telaah terhadap alam raya, masyarakat dan diri sendiri, serta bacaan tertulis, baik suci maupun tidak.

2) Surat Al-Qalam ayat 1

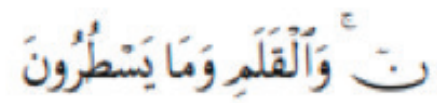

Artinya; "Nun, demi kalam dan apa yang mereka tulis”. (QS. Al-Qalam: 1)

Kata kunci dalam ayat ini adalah al qalam/ pena. Ada yang memahami dalam arti sempit yaitu pena tertentu, dan ada juga yang memahaminya secara umum yaitu alat tulis apapun (termasuk komputer yang paling canggih sekalipun). Menurut M. Quraish Shihab pemahaman secara umum lebih tepat, dan ini sejalan dengan perintah membaca yang merupakan wahyu pertama (Shihab, 2002: 379).

3) Surat an-Nisaa' ayat 83

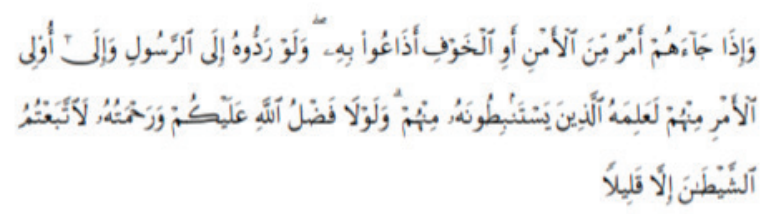

Artinya; Dan apabila datang kepada mereka suatu berita tentang keamanan ataupun ketakutan, mereka lalu menyiarkannya. dan kalau mereka menyerahkannya kepada Rasul dan ulil Amri di antara mereka, tentulah orang-orang yang ingin mengetahui kebenarannya (akan dapat) mengetahuinya dari mereka (rasul dan ulil Amri). kalau tidaklah Karena karunia dan rahmat Allah kepada kamu, tentulah kamu mengikut syaitan, kecuali sebahagian kecil saja (diantaramu). (QS. An Nisaa': 83)

M. Quraish Shihab (Shihab, 2002: 83-84) dalam tafsir Al-Mishbah mengatakan bahwa ayat ini merupakan salah satu tuntunan pokok dalam penyebaran informasi. Menurut asy-Syatibi "tidak semua apa yang diketahui boleh disebarluaskan, walaupun ia bagian dari informasi tentang pengetahuan hukum. Infor- 
masi ada bagian-bagiannya, ada yang dituntut untuk disebarluaskan, ada juga yang tidak diharapkan sama sekali disebarluaskan, atau baru disebarluaskan setelah mempertimbangkan keadaan, waktu, atau pribadi. Tidak semua informasi disampaikan sama kepada yang pandai dan bodoh, atau anak kecil dan dewasa, juga tidak semua pertanyaan perlu dijawab. Rumus penyebaran berita atau informasi ini adalah paparkanlah masalah yang akan anda informasikan setelah dipertimbangkan dengan matang, kemudian perhatikanlah dampaknya berkaitan dengan waktu dan masyarakat. Kalau informasinya tidak menimbulkan dampak negatif, maka paparkanlah informasi dengan banyak pertimbangan nalar, jika berita atau informasi tersebut tidak mengena dengan apa yang disampaikannya, maka sebaiknya berdiam diri karena sesuai dengan kemaslahatan agama dan akal.

Menurut Ibnu Kasir (2007: 344-346) hal ini merupakan pengingkaran terhadap orangorang yang tergesa-gesa dalam menanggapi berbagai urusan sebelum meneliti kebenarannya, lalu ia memberitakan dan menyiarkannya, padahal belum tentu hal itu benar.

4) Surat Hujurat ayat 6

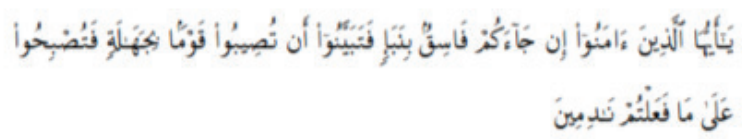

Artinya; "Hai orang-orang yang beriman, jika datang kepadamu orang fasik membawa suatu berita, Maka periksalah dengan teliti agar kamu tidak menimpakan suatu musibah kepada suatu kaum tanpa mengetahui keadaannya yang menyebabkan kamu menyesal atas perbuatanmu itu"(QS. Hujurat: 6).

أبن Kata kunci dalam ayat ini adalah "naba" yang diartikan sebagai berita yang penting. Berbeda dengan kata ربخ 'khabar' yang berarti kabar secara umum, baik penting atau tidak. Dari sini terlihat perlunya memilah informasi. Apakah itu penting atau tidak, dan memilah pula pembawa informasi apakah dapat dipercaya atau tidak. Orang beriman tidak dituntut untuk menyelidiki kebenaran informasi dari siapapun yang tidak penting, bahkan didengarkan tidak wajar, karena jika demikian maka akan banyak energi dan waktu yang terbuang untuk hAl-hal yang tidak penting.

Menurut Ibnu Kasir (2007:300), Allah SWT memerintahkan (kaum mukmin) untuk memeriksa dengan teliti berita dari orang-orang fasik, dan hendaklah mereka bersikap hati-hati dalam menerimanya dan jangan menerima begitu dengan begitu saja, yang akibatnya akan membalikkan kenyataan. Orang yang menerima dengan begitu saja berita darinya, berarti sama dengan mengikuti jejaknya.

5) Surat An Nuur ayat 19

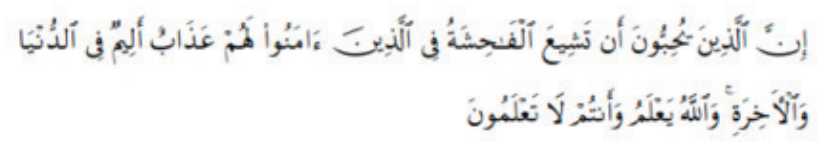

Artinya; " Sesungguhnya orang-orang yang ingin agar (berita) perbuatan yang amat keji itu tersiar di kalangan orangorang yang beriman, bagi mereka azab yang pedih di dunia dan di akhirat. dan Allah mengetahui, sedang, kamu tidak Mengetahui”. (QS. An Nuur: 19)

Ayat ini dapat dijadikan petunjuk bagi yang berkecimpung dalam bidang informasi, di sini terbaca tanggungjawab mereka dalam menyampaikan informasi, yang seharusnya tidak membawa dampak negatif dalam masyarakat. Adalah baik menyampaikan informasi yang benar dan positif, asal tidak berlebihan, sehingga menjurus pada pujian yang menjerumuskan, sedang yang negatif dianjurkan agar tidak dikemukakan kecuali dalam batas yang diperlukan. Berita atau informasi tidak boleh menelanjangi seseorang untuk membuktikan kejahatannya, juga di larang menginformasikan kejahatan/ketidakwajaran yang dapat merangsang timbulnya kejahatan baru, tidak juga mengungkap perseteruan orang, sehingga lebih memperuncing keadaan (Shihab, 2002: 306).

Melalui ayat-ayat di atas, jelaslah bahwa berita di media massa harus memiliki kejujuran, keakuratan, keadilan (tidak memihak salah seorang) dan dapat dipertanggungjawabkan. Jika digambarkan proses komunikasi massa dalam Al-Qur'an akan terbentuk serangkaian berita sebagai berikut: 


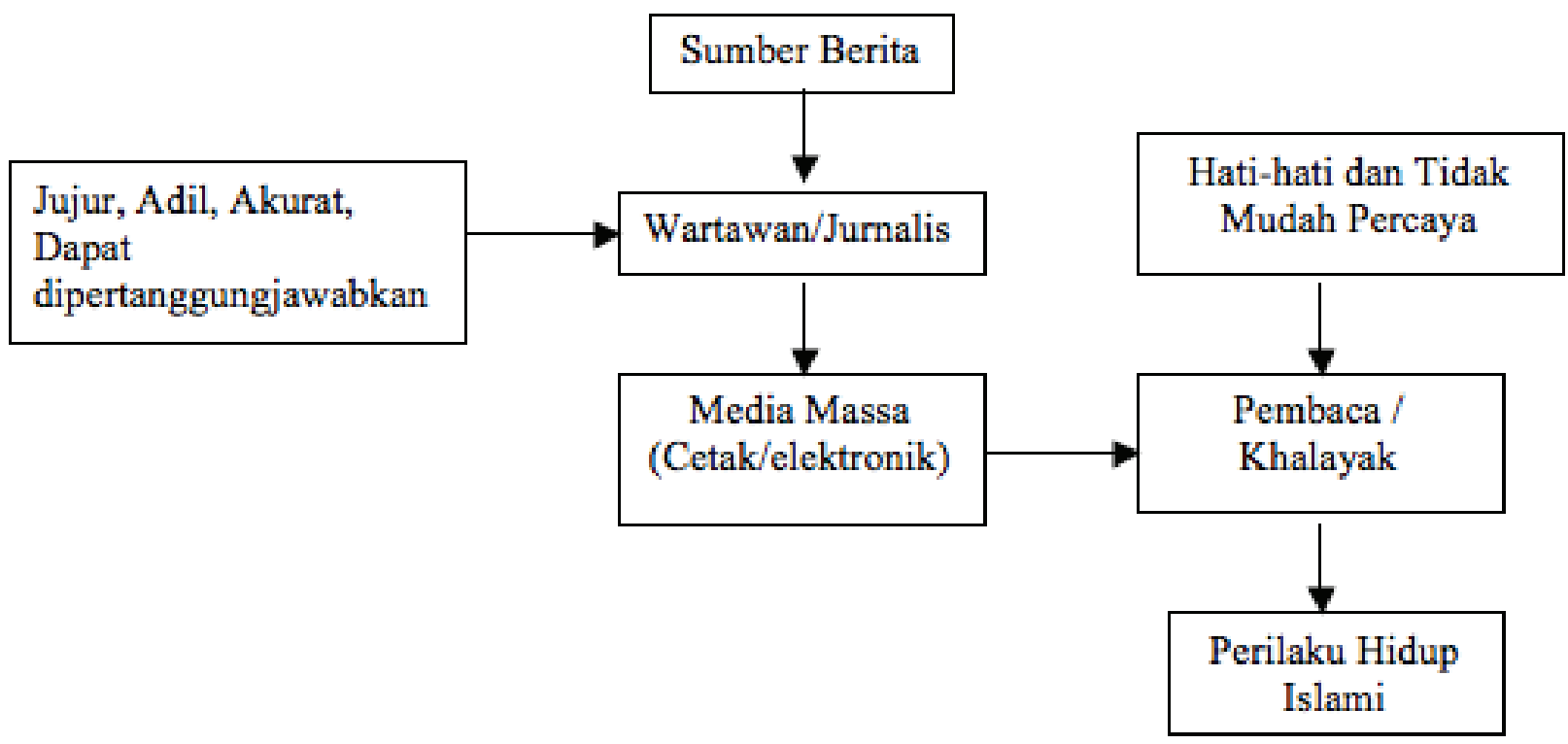

Gambar 2. 2 Proses Pemberitaan Menurut Al-Qur'an

Keterangan:

Sumber berita adalah peristiwa, kejadian atau orang yang dijadikan obyek berita. Wartawan/ jurnalis dalam memberitakan harus jujur, adil, akurat, dan dapat dipertanggungjawabkan beritanya karena berimplikasi langsung pada pembacanya (khalayak). Oleh karena itu bagi khalayak (pembaca/pendengar/pemirsa) harus hati-hati dan tidak boleh mudah percaya begitu saja karena akan menjadi penuntun dalam setiap perilaku hidup.

Keempat, akar komunikasi antarbudaya dalam Al -Qur'an. Untuk memberi arah yang jelas keterkaitan akar komunikasi dalam alQur'an diperlukan definisi komunikasi antarbudaya yang akan digunakan sebagai pijakan untuk mengklasifikasi ayat terkait dengan komunikasi antarbudaya.

Komunikasi antarbudaya adalah komunikasi yang terjadi antara orang-orang yang berbeda bangsa, ras, bahasa, agama, tingkat pendidikan, status sosial atau bahkan jenis kelamin (Mulyana, 2000: v). Komunikasi antarbudaya merupakan komunikasi antarpribadi yang dilakukan oleh komunikator dan komunikan yang berbeda budaya, bahkan dalam satu bangsa sekalipun (Liliweri, 2001: 15). Konteks komunikasi antarbudaya inilah yang akan digali dalam Al-Qur'an, seperti apa gambaran dan aplikasinya.
1) Surat Al Hujurat ayat 13

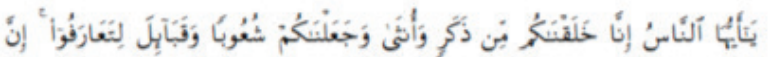

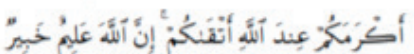

Artinya; "Hai manusia, Sesungguhnya kami menciptakan kamu dari seorang laki-laki dan seorang perempuan dan menjadikan kamu berbangsa-bangsa dan bersuku-suku supaya kamu saling kenAl-mengenal. Sesungguhnya orang yang paling mulia diantara kamu disisi Allah ialah orang yang paling taqwa diantara kamu. Sesungguhnya Allah Maha mengetahui lagi Maha Mengenal”. (QS. Al Hujurat: 13)

Ayat ini menjelaskan tentang prinsip dasar hubungan antar manusia, dengan panggilan

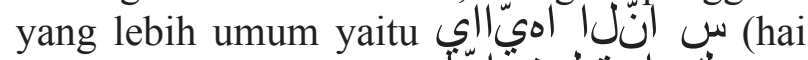

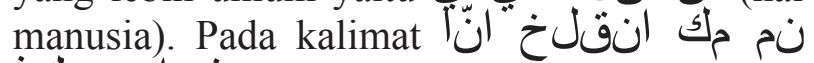
ن egaskan bahwa semua manusia derajat kemanusiaannya sama di sisi Allah, tidak ada perbedaan pada nilai kemanusiaan antara laki-laki dan perempuan karena semua diciptakan dari seorang laki-laki dan seorang perempuan, yang kemudian ditutup dengan kalimat مكاقت ملإنادن, sesungguhnya yang paling mulia di antara kamu di sisi Allah adalah yang 


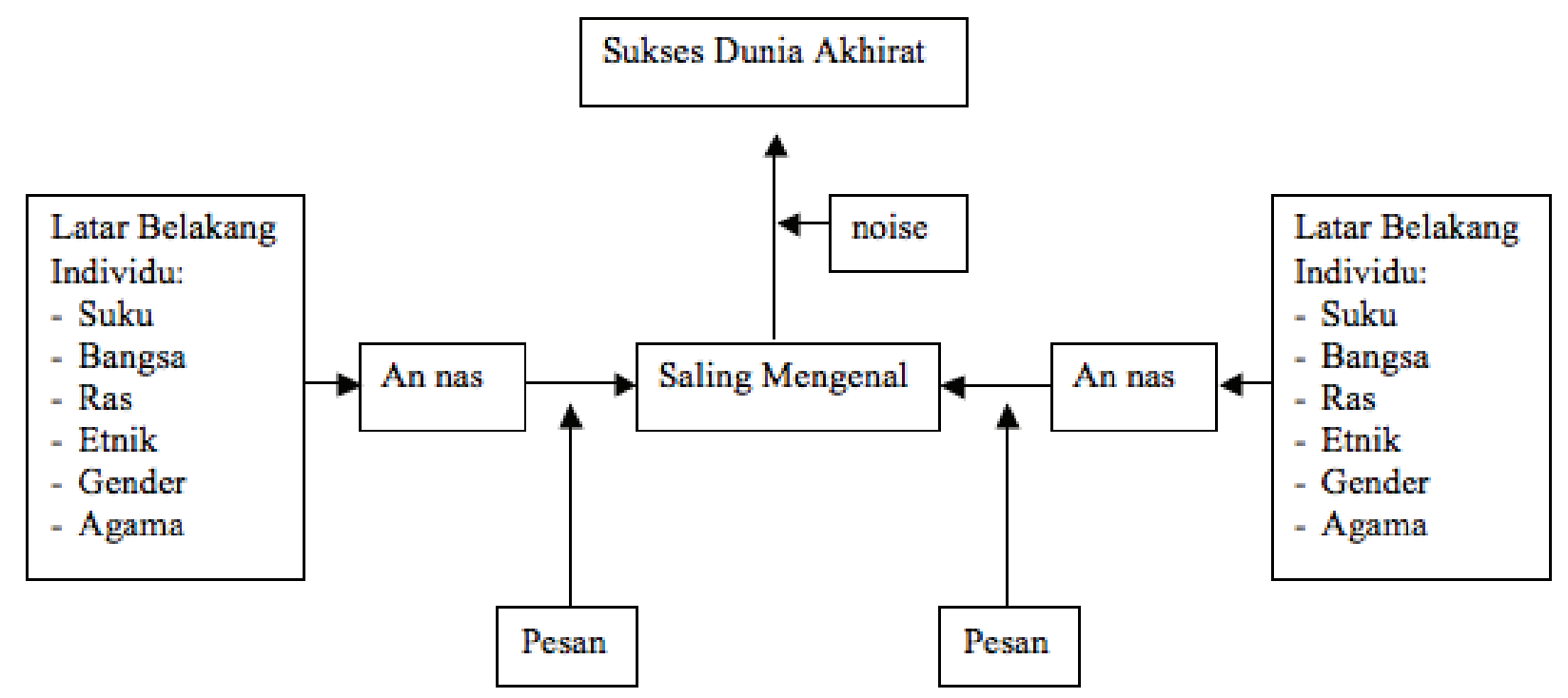

Gambar 2. 3 Model Komunikasi Antarbudaya Dalam Al-Qur'an

paling bertaqwa (Shihab, 2002: 260).

Kata بوعش syu'ub adalah bentuk jamak dari kata ب sya'b. Kata ini digunakan untuk menunjuk kumpulan dari sekian تلبيبق qabilah yang biasa diterjemahkan suku yang merujuk kepada satu kakek. Qabilah / suku pun terdiri dari sekian banyak kelompok keluarga yang dinamai $\varepsilon^{\prime}$ j 'imarah, dan yang ini terdiri dari lagi dari sekian banyak kelompok yang dinamai نطب batn. Di bawah batn ada sekian دخف fakhdz hingga akhirnya sampai pada himpunan keluarga terkecil. Terlihat dari penggunaan kata sya 'b bahwa ia bukan menunjuk kepada pengertian bangsa sebagaimana dewasa ini. Kata اوفر اؤت ta 'arafu diambil dari kata 2 'arafa yang berarti mengenal. Patron kata yang digunakan ayat ini mengandung makna timbal balik, dengan demikian ia berarti saling mengenal (Shihab, 2002: 261-262).

Menurut Ibnu Kasir (2007: 347) bahwa Allah meneceritakan kepada manusia bahwa Dia telah menciptakan mereka dari diri yang satu dan darinya Allah menciptakan istrinya, yaitu Adam dan Hawa, kemudian Dia menjadikan mereka berbangsa-bangsa. Pengertian bangsa dalam bahasa arab adalah sya 'bun yang artinya lebih besar daripada kabilah, sesudah kabilah terdapat tingkatan-tingkatan lainnya yang lebih kecil seperti fasa'il (puak), asya-ir (bani), ama-ir afkhad, dan sebagainya.

2) Surat Al-Kafirun ayat 6

Dalam konteks lain, dijelaskan pula tentang konsep komunikasi antar agama yang tertuang dalam surat Al-Kafirun avat 6 sebagai berikut;

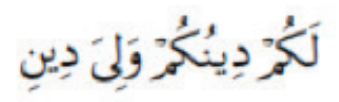

Artinya; "Untukmu agamamu, dan untukkulah, agamaku” (QS. Al-Kafirun: 6).

Ayat ini menetapkan cara pertemuan dalam kehidupan bermasyarakat yaitu untukmu secara khusus agama kamu. Agama itu tidak menyentuhku sedikitpun, kamu bebas untuk mengamalkannya sesuai kepercayaan kamu, dan untukku juga secara khusus agamaku, aku pun mestinya memperoleh kebebasan untuk melaksanakannya, dan kamu tidak akan disentuh sedikitpun olehnya.

Kata din dapat berarti agama, atau balasan, atau kepatuhan. Didahulukannnya kata lakum dan liya dalam kalimat ini, memiliki fungsi menggambarkan kekhususan, karena itu pula masing-masing agama biarlah berdiri sendiri dan tidak perlu dicampurbaurkan. Kata din diartikan agama, tidak berarti nabi diperintahkan untuk mengakui kebenaran anutan mereka. Ayat ini hanya mempersilahkan mereka menganut apa yang mereka yakini (Shihab, 2002: 581).

Dengan demikian, Al-Qur'an telah memberikan petunjuk yang sempurna di bidang komunikasi antar budaya. Model atau pola komunikasi antarbudaya dalam Al-Qur'an dapat digambarkan pada Gambar 2. 3 di atas. 
Penjelasan:

1. Model komunikasi ini merupakan hasil interpretasi dan modifikasi dari Al-Qur'an surat hujuraat ayat 13 .

2. Hakikat manusia diciptakan di bumi ini adalah untuk saling mengenal (komunikasi) antar sesama baik berlatar belakang suku, bangsa, etnik dan sebagainya

3. Model atau diagram komunikasi ini diawali dari setiap manusia (an nas) itu diciptakan oleh Allah dengan beragam jenis suku, bangsa, etnik, ras, jenis kelamin/gender, dan agama. An nas (manusia) diciptakan sebagai pusat informasi. Informasi inilah yang kemudian diolah sebagai pesan yang akan disampaikan kepada antar sesama manusia yang berlatar belakang budaya yang berbeda.

4. Saling mengenal merupakan implementasi komunikasi antar manusia yang bersifat timbal balik (sirkuler). Saling mengenal juga dapat dimaknai sebagai suasana keakraban antar peserta komunikasi (an nas).

5. Sukses Dunia Akhirat: berdasarkan prinsip saling mengenal tersebut akan tercapai hakikat tujuan komunikasi adalah sukses dunia akhirat. Dalam perjalanan menuju hakikat komunikasi tersebut an nas tidak dapat melepaskan diri dari gangguan (noise).

Kelima, akar komunikasi organisasi dalam Al-Qur'an. Konteks komunikasi organisasi dijelaskan dengan konteks perintah melaksanakan dakwah (amar ma'ruf nahi munkar) yang sangat urgen untuk dilaksanakan oleh lembaga/ organisasi. Pada tataran inilah ruang komunikasi organisasi dapat dijelaskan dalam Al-Qur'an sebagaimana firmanNya sebagai berikut:

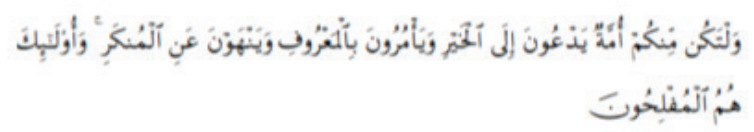

Artinya; "Dan hendaklah ada di antara kamu segolongan umat yang menyeru kepada kebajikan, menyuruh kepada yang ma'ruf dan mencegah dari yang munkar; merekalah orang-orang yang beruntung"(QS. Ali Imron: 104).

Kalau tidak semua anggota masyarakat dapat melaksanakan fungsi dakwah, maka hendaklah ada di antara kamu, wahai orang-orang yang beriman, segolongan ummat yakni organisasi atau sangat berarti bagi kehidupan manusia.

Memang dalam Islam tidak mengenal kata atau defenisi komunikasi dan ilmu komunikasi. Baik di dalam Al-Qur'an maupun Hadits tidak akan ditemui kata dan pengertian tersebut. Namun demikian, dari kedua sumber ajaran Islam tersebut, dapat ditemui beberapa prinsip dasar yang berkaitan dengan komunikasi (Amir, 1999: 11).

Al-Qur'an selalu berada di tengah-tengah kehidupan, alam dan relasi kemanusiaan untuk mengawal peradaban kemanusiaan. Al-Qur'an berada di depan sebagai panduan, di tengah realitas sebagai sumber spirit dan inspirasi, serta dibelakang sebagai pendorong atau motivasi (Syahputra, 2007: 57).

Al-Qur'an juga menyebut komunikasi sebagai salah satu fitrah manusia (Rakhmat, 1993: 76) dengan merujuk surat Ar-Rahman ayat 1-4 bahwa manusia diciptakan dengan kemampuan berkomunikasi (al bayan). Dengan demikian maka sesungguhnya dalam Al-Qur'an telah terkandung semua aspek ajaran tentang komunikasi. Hanya saja orang-orang barat lebih dulu mengembangakan ajaran al-Qur'an melalui pengembangan ilmiah tentang pengetahuan komunikasi.

\section{SIMPULAN}

Simpulan dari penelitian ini adalah akar komunikasi intrapersonal dalam Al-Qur'an menempatkan hati (immaterial) sebagai pusat kendali seluruh jiwa memberi stimuli pada indera pendengaran dan penglihatan (material), dan menghasilkan pikiran. Akar komunikasi interpersonal dalam Al-Qur'an lebih berpijak pada etika komunikasi atau cara berbicara pada orang lain dengan hikmah, mauidhah, dan mujadalah yang dilandasi prinsip qawlan sadidan, qawlan balighan, qawlan maysuran, qawlan layyinan, qawlan kariman, qawlan ma'rufan. Akar komunikasi massa dalam Al-Qur'an menempatkan Al-Qur'an sendiri sebagai pusat informasi/berita yang memiliki kebenaran mutlak. Al-Qur'an memberikan tuntunan agar manusia dalam memberi informasi/berita pada orang lain harus disertai dengan kejujuran, keadilan, keakuratan, dan dapat dipertanggungjawabkan. Al-Qur'an menghimbau kepada khalayak untuk berhati-hati (tidak mudah percaya) dalam menerima informasi atau berita. Akar komunikasi antarbudaya dalam 
Tabel 2. 1 Keterkaitan Konsep Komunikasi Dalam Al-Qur’an Dengan Komunikasi Menurut Para Ahli (Barat)

\begin{tabular}{|c|c|c|c|}
\hline No & Konsep Al-Qur'an & Keterkaitan & Konsep Barat \\
\hline 01 & Komunikasi Intrapersonal & & \\
\hline & $\begin{array}{l}\text { Hati (immaterial) sebagai pusat } \\
\text { kendali seluruh jiwa memberi } \\
\text { stimuli pada indera pendengaran } \\
\text { dan penglihatan (material), dan } \\
\text { menghasilkan pikiran }\end{array}$ & $\begin{array}{l}\text { Konsep Al-Qur'an memulai ko- } \\
\text { munikasi dari hati sebagai pusat } \\
\text { kendali, namun pada konsep } \\
\text { Barat dimulai dari sensasi yang } \\
\text { menghadirkan stimuli dari luar. } \\
\text { Kedua konsep memiliki kesa- } \\
\text { maan di hasil akhir yaitu ber- } \\
\text { pikir. }\end{array}$ & $\begin{array}{l}\text { Komunikasi dengan diri } \\
\text { sendiri, dengan proses } \\
\text { sensasi, asosiasi, persepsi, } \\
\text { memori, dan beripikir }\end{array}$ \\
\hline 02 & Komunikasi Interpersonal & & \\
\hline
\end{tabular}

Lebih berpijak pada etika ko- Konsep Al-Qur'an menggumunikasi atau cara berbicara nakan etika sebagai tuntunan pada orang lain dengan hikmah, utama agar lawan bicara tidak mauidhah, dan mujadalah yang meninggalkannya, namun pada dilandasi prinsip qawlan sa- konsep Barat menggunakan didan, qawlan balighan, qawlan batasan peserta komunikasi maysuran, qawlan layyinan, qa- sebagai ruang yang terbatas. wlan kariman, qawlan ma'rufan. Kedua konsep memiliki kesamaan di hasil akhir yaitu tentang cara/teknik atau etika.
Lebih berpijak pada proses terjadinya komunikasi dengan batasan peserta (dua atau tiga peserta komunikasi) dengan menggunakan teknik persuasif, informatif, atau koersif.

\section{$03 \quad$ Komunikasi Massa}

Al-Qur'an sendiri merupakan pusat informasi / berita yang memiliki kebenaran mutlak. Al-Qur'an memberikan tuntunan agar manusia dalam memberi informasi / berita pada orang lain harus disertai dengan kejujuran, keadilan, keakuratan, dan dapat dipertanggungjawabkan. Al-Qur'an menghimbau kepada khalayak untuk berhati-hati (tidak mudah percaya) dalam menerima informasi atau berita.

\section{Komunikasi Antarbudaya}

Konsep Al-Qur'an di mulai dari Kedua konsep sama-sama Konsep Barat lebih mehakikat manusia diciptakan di memiliki penekanan pentingbumi yaitu untuk saling men- nya memahami budaya yang genal (komunikasi) antar sesama berbeda untuk mencapai tujuan baik berlatar belakang agama, hidup, yaitu khalifah di bumi. suku, bangsa, etnik, jenis kelamin dan sebagainya
Konsep Al-Qur'an berpijak berita agar tidak menjerumus- kan masyarakat. Konsep Barat lebih kuat diklasifikasi media. Namun keduanya sama-sama memiliki kepentingan terhadap berita yang akan diinforma- sikan.
Lebih cenderung pada pemilihan aspek teknologis media massa yaitu media cetak dan elektronik. Kla- sifikasi media cetak teridiri dari surat kabar, majalah, tabloid, dan lain sebagain- ya. Sedangkan media elek- tronik terdiri dari radio, $\mathrm{TV}$, internet dan lain se- bagainya. nekankan pada pemahaman latar belakang budaya seseorang ketika berkomunikasi agar ada kesepahaman bersama

\section{Komunikasi Organisasi}

Konsep Al-Qur'an memerintah- Konsep Al-Qur'an lebih cend- Konsep Barat lebih berbickan sebagian masyarakat untuk erung organisasi dijadikan semembentuk organisasi atau lem- bagai tempat atau sarana dakbaga untuk mengoptimalkan usa- wah. Namun konsep Barat ha amar ma'ruf dan nahi munkar lebih cenderung berorientasi ke profit. Namun keduanya juga sama-sama menekankan pentingnya efektivitas komunikasi dalam organisasi. ara secara umum tentang organisasi, baik organisasi profit maupun non-profit. Juga menekankan pentingnya efektivitas komunikasi dalam organisasi untuk mencapai tujuan lembaga / organisasi. 
kelompok yang pandangan mengarah kepadanya untuk diteladani dan didengar nasehatnya, yang mengajak orang lain secara terus menerus tanpa bosan dan lelah kepada kebajikan yaitu petunjuk-petunjuk Ilahi, menyuruh masyarakat kepada yang ma'ruf yaitu kepada nilai-nilai luhur serta adat istiadat yang diakui baik oleh masyarakat mereka, selama tidak bertentangan dengan nilainilai Ilahiyah, dan mencegah mereka dari yang munkar yaitu yang dinilai buruk lagi yang diingkari oleh akal sehat masyarakat.

Kata ملكنم minkum pada ayat ini ada ulama yang memahaminya dalam arti sebahagian, sehingga dengan demikian, perintah dakwah yang dipesankan dalam ayat ini tidak tertuju pada setiap orang. Bagi mereka yang memahami demikian, maka ayat ini mengandung dua macam perintah; yang pertama, kepada seluruh umat Islam agar membentuk dan menyiapkan satu kelompok/organisasi khusus yang bertugas melaksanakan dakwah, sedang perintah kedua, adalah kepada kelompok/organisasi khusus itu untuk melaksanakan dakwah kepada kebajikan dan ma'ruf dan mencegah kemunkaran.

Ayat di atas menggunakan dua kata yang berbeda dalam rangka perintah berdakwah. Pertama adalah kata نو عدي yad'un yaitu mengajak, dan kedua adalah نورماي ya'murun yaitu memerintahkan. Sayyid Quttub mengemukakan bahwa penggunaan dua kata yang berbeda itu menunjukkan keharusan adanya dua kelompok/ organisasi dalam masyarakat Islam. Kelompok pertama yang bertugas mengajak dan kelompok kedua yang bertugas memerintah dan melarang. Kelompok kedua ini tentunya yang memiliki kekuasaan di bumi (pemerintah) (Shihab, 2002: 162-163).

Menurut Ibnu Kasir (2007: 56), makna yang dimaksud dalam ayat ini adalah hendaklah ada segolongan orang dari kalangan umat ini yang bertugas untuk mengemban urusan tersebut, sekalipun urusan tersebut memang diwajibkan pula atas individu dari umat ini. Hal ini berarti telah mengisyaratkan adanya organisasi.

Terakhir, keterkaitan konsep komunikasi dalam Al-Qur'an dengan konsep komunikasi dalam perpektif ilmu komunikasi. Komunikasi merupakan salah satu kebutuhan hakiki manusia. Tanpa komunikasi individu tidak mampu membentuk masyarakat. Tanpa komunikasi juga tidak akan menimbulkan interaksi dalam kehidupan masyarakat. Oleh karena itu komunikasi menjadi
Al-Qur'an di mulai dari hakikat manusia diciptakan di bumi yaitu untuk saling mengenal (komunikasi) antar sesama baik berlatar belakang agama, suku, bangsa, etnik, jenis kelamin dan sebagainya. Akar komunikasi organisasi dalam Al-Qur'an memerintahkan sebagian masyarakat (umat) untuk membentuk organisasi atau lembaga untuk mengoptimalkan usaha amar ma'ruf dan nahi munkar. Dan keterkaitan konsep komunikasi dalam Al-Qur'an dengan konsep komunikasi Barat mengandung nilai saling menjelaskan. Artinya bagi orang muslim Al-Qur'an merupakan petunjuk dalam kehidupan, sedangkan komunikasi barat dapat dijadikan sebagai sarana penjelas apa yang ada dalam Al-Qur'an.

Untuk melengkapi hasil penelitian ini disarankan untuk meneliti lagi tentang item-item yang menjadi akar komunikasi secara mendetail yang ada dalam Al-Qur'an, meneliti lagi tentang kandungan Al-Qur'an terkait dengan fenomena komunikasi yang ada dalam kehidupan manusia.

\section{DAFTAR PUSTAKA}

Ad-Dimasyqi, Al Imam Abul Fida Ismail Ibnu Kasir, Tafsir Ibnu Kasir. (2007). Terjemahan: Bahrun Abu Bakar, (Bandung: Sinar Baru Algensindo)

Amir, M. (1999). Etika Komunikasi Massa dalam Pandangan Islam. (Jakarta: Logos Wacana Ilmu)

Departemen Agama RI. Al-Qur'an dan Terjemahannya, ( Surabaya: UD. Mekar Surabaya)

Effendy, O. U. (2000). Ilmu, Teori dan Filsafat Komunikasi. (Bandung: Citra Aditya Bakti)

Muis, A. (2001) Komunikasi Islami, (Bandung: Remaja Rosyda Karya)

Nasution, H. (1986). Akal dan Wahyu Dalam Islam. (Jakarta: Universitas Indonesia UIPRESS)

Rakhmat, J. (1993). Islam Aktual, (Bandung: Mizan)

Shihab, M. Q. dkk. (2002). Ensiklopedia AlQur'an : Kajian Kosakata, Jilid 1, (Jakarta : Lentera Hati)

Shihab, M. Q. (2002). Tafsir Al-Mishbah; Pesan, Kesan dan Keserasian Al-Qur'an, Volume I, (Jakarta: Lentera Hati )

Syahputra, I. (2007). Komunikasi Profetik, (Bandung: Simbiosa Rekatama Media)

Yunus, M. (1973). Kamus Arab - Indonesia, (Padang: IAIN Imam Bonjol) 